\title{
PERBEDAAN PENGARUH TEKNIK SLOW STROKE BACK MASSAGE DENGAN TEKNIK ENDORPHIN MASSAGE TERHADAP PENURUNAN NYERI PERSALINAN FASE AKTIF DI PUSKESMAS IMBANAGARA KABUPATEN CIAMIS TAHUN 2018
}

\section{OLEH:}

\author{
(Maemunawaroh $^{1}$, Dede Gantini ${ }^{2}$, Uly Artha Silalahi ${ }^{3}$ )
}

\section{A. ABSTRACT}

Nyeri persalinan merupakan pengalaman subjektif tentang sensasi fisik yang terkait dengan kontraksi uterus dilatasi dan penipisan serviks, serta penurunan janin selama persalinan. Nyeri persalinan menjadi penyebab terjadinya partus lama dengan sumbangsih $5 \%$ terhadap penyebab kematian. Penanganan nyeri persalinan dapat diberikan dengan beberapa teknik non farmakologi yaitu Slow stroke back massage dan endorphin massage.Penelitian ini bertujuan untuk mengetahui pengaruh Stroke Back Massage dan Endorphin Massage terhadap Penurunan Nyeri Persalinan di Puskesmas Imbanagara Kabupaten Ciamis.Jenis penelitian yang dilakukan dalam penelitian ini adalah Quasi eksperimental. Penelitian ini masuk dalam bentuk two group pretest post test design. Populasi penelitian adalah semua ibu Inpartu Fase Aktif di Wilayah Kerja Puskesmas Imbanagara Kabupaten Ciamis sebanyak 32 orang. Teknik pengambilan sampel dalam penelitian ini menggunakan Total Sampling. Jumlah sampel pada penelitian ini yaitu 32 orang yang terbagi menjadi 2 kelompok dengan 2 perlakuan yang berbeda.Hasil penelitian kedua teknik efektif menurunkan nyeri namun jika dilihat dari persentase setelah pemberian intervensi pada teknik Slow Stroke Back Massage sebagian besar nyeri sedang 62,5\% lebih efektif dibandingkan penurunan nyeri pada teknik Endorphin Massage sebagian besar nyeri berat 75\%. Diperoleh nilai p-value sebesar 0,03 karena p-value< $\alpha$ (0,05), maka Ho ditolak, yang berarti bahwa ada perbedaan pengaruh teknik Slow Stroke Back Massage dengan teknik Endorphin Massage. Penelitian ini direkomendasikan kepada bidan agar dapat memenuhi kebutuhan ibu akan rasa nyaman dalam nyeri persalinan.

\section{Kata Kunci : Nyeri Persalinan, Slow Stroke Back Massage,Endorphin Massage.}




\section{B. LATAR BELAKANG}

Nyeri merupakan kondisi berupa perasaan yang tidak menyenangkan. Sifatnya sangat subjektif karena perasaan nyeri berbeda pada setiap orang dalam hal skala atau tingkatannya, dan hanya orang tersebutlah yang dapat menjelaskan atau mengevaluasi rasa nyeri yang dialaminya. Bagian tubuh yang sering diderita keluhan nyeri adalah leher, tangan, kaki, dan daerah pinggang. Selain obat dan terapi, untuk pertolongan pertama bisa dilakukan dengan kompres hangat untuk membantu pengurangan nyeri persalinan (Bandiyah, S. 2009).

Rasa nyeri pada persalinan adalah manifestasi dari adanya kontraksi (pemendekan) otot rahim. Kontraksi inilah yang menimbulkan rasa sakit pada pinggang, daerah perut dan menjalar kearah paha. Nyeri persalinan disebabkan adanya regangan segmen bawah rahim dan servik serta adanya iskemia otot rahim (Judha, dkk, 2012). Nyeri persalinan dapat menimbulkan stres yang menyebabkan pelepasan hormon yang berlebihan seperti katekolamin dan steroid. Hormon ini dapat menyebabkan terjadinya ketegangan otot polos dan vasokonstriksi pembuluh darah. Hal ini dapat mengakibatkan penurunan kontraksi uterus, penurunan sirkulasi uteroplasenta, pengurangan aliran darah dan oksigen ke uterus, serta timbulnya iskemia uterus yang membuat impuls nyeri bertambah banyak (Sumarah, 2009).

Rasa nyeri merupakan hal yang normal terjadi dan merupakan bagian yang tidak dapat dipisahkan dari persalinan, sekitar 80\%-95\% wanita melahirkan melaporkan rasa nyeri yang hebat selama persalinan akibat dilatasi serviks dan penurunan presentasi bayi (Tournaire \& Theau Yonneau, 2007). Faktor his yang tidak normal baik kekuatan maupun sifatnya dapat menghambat kelancaran persalinan (Manauba, 2001 dalam Judha, dkk 2012). Nyeri persalinan merupakan penyebab terjadinya partus lama, partus lama memberikan sumbangsih $5 \%$ terhadap penyebab kematian ibu di Indonesia.

Pada tahun 2015 jumlah Angka Kematian Ibu (AKI) di Indonesia tergolong tinggi dibandingkan dengan negara Asean lainnya yaitu mencapai 305 per 100.000 kelahiran (Kemenkes, 2015). AKI di Jawa Barat tahun 2017 sampai bulan Agustus berjumlah 448 jiwa (Dinas Kesehatan Jawa Barat, 2017). AKI di Kabupaten Ciamis pada tahun 2016 berjumlah 15 orang dan penyumbang terbanyak angka kematian di wilayah kerja Puskesmas Imbanagara sejumlah 3 orang (Dinkes Kabupaten Ciamis, 2016). Sedangkan angka kejadian partus lama di wilayah kerja Puskesmas Imbanagara sebanyak 5 kasus pada tahun 2016.

Berdasarkan alasan tersebut di atas, tindakan non farmakologis dalam manajemen nyeri merupakan trend baru yang dapat dikembangkan dan merupakan metode alternatif dapat digunakan pada ibu untuk mengurangi nyeri persalinan. Relaksasi, teknik pernafasan, pergerakan dan perubahan posisi, massage, hidroterapi, terapi panas/dingin, musik, guided imagery, akupressur, dan aromaterapi merupakan beberapa teknik non farmakologis yang dapat meningkatkan kenyamanan ibu saat bersalin dan mempunyai pengaruh pada koping yang efektif terhadap pengalaman persalinan (Arifin, 2008). Adapun beberapa teknik massage yang dapat mengurangi nyeri persalinan yaitu slow stroke back massage dan endorphine massage.

Endorphin Massage merupakan sebuah terapi sentuhan/pijatan ringan 
yang cukup penting diberikan pada wanita hamil, di waktu menjelang hingga saatnya melahirkan. Hal ini disebabkan karena pijatan merangsang tubuh untuk melepaskan senyawa Endorphin yang merupakan pereda rasa sakit dan dapat menciptakan perasaan nyaman (Kuswandi, 2011).

Adapun Slow Stroke Back Massage dapat menjadi alternatif baru dalam mengurangi nyeri persalinan. Stimulasi kutan Slow Stroke Back Massage dapat mengurangi nyeri dengan cara merangsang pengeluaran hormon endorphin dan menghalangi transmisi stimulus nyeri (Potter, 2005). Stimulasi ini dilakukan di area punggung yang dekat dengan saraf spinalis torakal bawah (T10-T12) dan saraf spinalis lumbal atas (L1) yang merupakan tempat diteruskannya rangsangan nyeri dari korpus uteri dan servik (Andarmoyo 2013).

Studi pendahuluan yang penulis lakukan di wilayah kerja Puskesmas Imbanagara Kabupaten Ciamis pada tanggal 8 Desember 2017 pada ibu yang akan menjelang persalinan pada kala I pembukaan 7 setelah dilakukan wawancara mengatakan bahwa nyeri yang dirasakan oleh ibu adalah termasuk nyeri berat. Berdasarkan data dan penjelasan diatas maka penulis tertarik untuk melakukan penelitian mengenai perbedaan pengaruh teknik slow stroke back massage dengan teknik endorphin massage terhadap penurunan nyeri persalinan di Puskesmas Imbanagara Kabupaten Ciamis.

\section{METODE PENELITIAN}

Penelitian ini termasuk dalam penelitian Quasi eksperimental. Penelitian ini masuk dalam bentuk two group pretest post test design.Populasi dan sampel penelitian ini adalah semua ibu bersalin kala I fase aktif di wilyah kerja Puskesmas Imbangara pada bulan Januari-Februari sebanyak 32 orang dengan teknik total sampling. Instrumen penelitian ini adalah : Numeric Rating Scale, SOP Slow Stroke Back Massage, SOP Endorphin Massage.Analisa univariat digunakan untuk melihat gambaran nyeri persalinan pada Ibu Inpartu Kala I Fase Aktif di Puskesmas Imbanagara Kecamatan Ciamis. Data yang diperoleh dikumpulkan dan dituangkan ke dalam tabel distribusi frekuensi dengan perhitungan frekuensi dan persentasi tingkat nyeri persalinan secara deskriptif kuantitatif.

Analisis bivariat pada penelitian ini menggunakan Uji Mann-Whitney $U$ Test yaitu uji statistik non parametrik yang digunakan untuk melihat perbedaan 2 sampel independent untuk skala data berjenis ordinal (Sari, 2015). Pada penelitian ini Uji Mann-Whitney $U$ Test dilakukan untuk mengetahui pengaruh slow stroke back massage dengan endorphin massage terhadap penurunan nyeri persalinan kala I fase aktif. Nilai interpretasi pada analisa bivariat jika $p$-value $<0,05$ berarti $\mathrm{Ha}$ diterima, artinya ada perbedaan pengaruh teknik slow stroke back massage dengan teknik endorphin massage terhadap penurunan nyeri persalinan. Jika Ha ditolak, artinya tidak ada perbedaan pengaruh teknik slow stroke back massage dengan teknik endorphin massage terhadap penurunan nyeri persalinan 


\section{HASIL PENELITIAN}

Tabel 1

Gambaran Intensitas NyeriPersalinanSebelum dan SesudahDiberikanPerlakuanSlowStroke Back Massage

\begin{tabular}{|c|c|c|c|c|c|c|c|c|}
\hline \multirow{3}{*}{ SSBM } & \multicolumn{6}{|c|}{ Nyeri Persalinan } & \multicolumn{2}{c|}{} \\
\cline { 2 - 8 } & \multicolumn{2}{|c|}{$\begin{array}{c}\text { Nyeri } \\
\text { Sedang }\end{array}$} & \multicolumn{2}{c|}{$\begin{array}{c}\text { Nyeri } \\
\text { Berat }\end{array}$} & $\begin{array}{c}\text { Nyeri } \\
\text { Sangat } \\
\text { Berat }\end{array}$ & \multicolumn{3}{c|}{ Jumlah } \\
\cline { 2 - 8 } & $\mathrm{f}$ & $\%$ & $\mathrm{~F}$ & $\%$ & $\mathrm{f}$ & $\%$ & $\mathrm{~N}$ & $\%$ \\
\hline Sebelum & 1 & 6,3 & 10 & 62,5 & 5 & 31 & 16 & 100 \\
& & & & & &, 3 & & \\
\hline Sesudah & 10 & 62,5 & 6 & 37,5 & 0 & 0 & 16 & 100 \\
\hline
\end{tabular}

Berdasarkan Tabel 4.1 menunjukkan bahwa nyeri persalinan pada ibu bersalin sebelum diberikan Slow Stroke Back Massage pada kategori nyeri sangat berat 5 orang $(31,3)$, nyeri berat 10 orang $(62,5 \%)$, nyeri sedang 1 orang $(6,3 \%)$ sedangkan setelah diberikan SlowStroke Back kategori tidak ada nyeri sangat berat, nyeri berat 6 orang $(37,5 \%)$, nyeri sedang 10 orang $(62,5 \%)$.

Tabel 2

Gambaran Intensitas NyeriPersalinanSebelum dan SesudahDiberikanPerlakuanEndorphin Massage

\begin{tabular}{|c|c|c|c|c|c|c|c|c|}
\hline \multirow{2}{*}{} & \multicolumn{6}{|c|}{ Nyeri Persalinan } & \multicolumn{2}{c|}{} \\
\cline { 2 - 8 } & \multicolumn{2}{|c|}{$\begin{array}{c}\text { Nyeri } \\
\text { Sedang }\end{array}$} & \multicolumn{2}{c|}{$\begin{array}{c}\text { Nyeri } \\
\text { Berat }\end{array}$} & \multicolumn{2}{c|}{$\begin{array}{c}\text { Nyeri } \\
\text { Sangat } \\
\text { Berat }\end{array}$} & \multicolumn{2}{c|}{ Jumlah } \\
\cline { 2 - 8 } & f & $\%$ & F & $\%$ & f & $\%$ & N & $\%$ \\
\hline Sebelum & 3 & 18,8 & 7 & 43,8 & 6 & 37,5 & 16 & 100 \\
\hline Sesudah & 4 & 25,0 & 12 & 75,0 & 0 & 0 & 16 & 100 \\
\hline
\end{tabular}

BerdasarkanTabel 4.2 menunjukkan bahwa nyeri persalinan pada ibu bersalin sebelum diberikan Endorphin Massage nyeri sangat berat 6 orang (37,5\%), nyeri beratyaitu 7 orang $(43,8 \%)$, nyeri sedang 3 orang $(18,8 \%)$ dan setelah diberikan Endorphin Massage pada ibu bersalin kategori yaitu tidak ada nyeri sangat berat, nyeri berat 12 orang $(75,0 \%)$, nyeri sedang 4 orang $(25,0 \%)$. 
Tabel 3

Perbedaan Pengaruh Teknik Slow Stroke Back Massage dengan Teknik Endorphin Massage Terhadap Nyeri Persalinan pada Ibu Bersalin di Wilayah Kerja Puskesmas Imbanagara Kabupaten Ciamis Tahun 2018

\begin{tabular}{|l|c|c|c|}
\hline & $\begin{array}{c}\text { Jumlah } \\
\text { Objek }\end{array}$ & z & $\begin{array}{c}\text { Signif } \\
\text { ikasi }\end{array}$ \\
\hline $\begin{array}{l}\text { Nyeri persalinan pada ibu bersalin } \\
\text { antara yang diberikan Slow Stroke } \\
\text { Back Massage dan Endorphin }\end{array}$ & 32 & -2.165 & 0.03 \\
\hline
\end{tabular}

Berdasarkan uji Mann Whitney didapatkan nilai p-valuesebesar 0,03 dan karena pvalue $0,03<\alpha(0,05)$, maka Ho ditolak, yang berarti bahwa ada perbedaan pengaruh penurunan nyeri persalinan pada ibu bersalin antara yang diberikan perlakuan slowstroke back massage dengan endorphinmassage di Wilayah Kerja Puskesmas Imbanagara Kabupaten

Ciamis

Tahun

2018.

\section{E. PEMBAHASAN}

1. Gambaran Intensitas Nyeri Persalinan pada Ibu Bersalin Sebelum dan Sesudah Diberikan Perlakuan SlowStroke Back Massage

Berdasarkan hasil penelitian menunjukkan bahwa nyeri persalinan pada ibu bersalin sebelum diberikan slowstroke back massage sebagian besar ada pada kategori nyeri berat yaitu nyeri sangat berat 5 orang $(31,3)$, nyeri berat 10 orang $(62,5 \%)$, nyeri sedang 1 orang $(6,3 \%)$ sedangkan setelah diberikan slowstroke back massage sebagian besar nyeri sedang 10 orang $(62,5 \%)$, nyeri berat 6 orang $(37,5 \%)$ dan tidak ada nyeri sangat berat.

Nyeri persalinan merupakan pengalaman subjektif tentang sensasi fisik yang terkait dengan kontraksi uterus, dilatasi dan penipisan serviks, serta penurunan janin selama persalinan. Respon fisiologis terhadap nyeri meliputi peningkatan tekanan darah, denyut nadi, pernapasan, keringat, dan ketegangan otot (Mathew et al, 2012 dalam Maryani, 2017).

Intensitas rasa nyeri dari pembukaan satu sampai pembukaan sepuluhakan bertambah tinggi dan semakin sering sebanding dengan kekuatan kontraksi dan tekanan bayi terhadap struktur panggul, diikuti regangan bahkan perobekan jalan lahir bagian bawah dari takada pembukaan sampai pada pembukaan 2 bisa berlangsung sekitar 8 jam.

Slowstroke back massage merupakan terapi manipulasi dengan pijatan lembut pada jaringan yang bertujuan memberikan efek terhadap fisiologis terutama pada vaskular, muskular, dan sistemsaraf pada tubuh. Slowstroke back 
massage tidak hanya memberikan relaksasi secara menyeluruh, namun juga bermanfaat bagi kesehatan seperti melancarkan sirkulasi darah, menurunkan tekanan darah, menurunkan respon nyeri, dan meningkatkan kualitas tidur (Afrila, Dewi, \& Erwin 2015). Usapan yang panjang dan lembut memberikan kesenangan dan kenyamanan bagi klien.

Mekanisme slowstroke back
massage yaitu meningkatkan
relaksasi dengan menurunkan
aktivitas saraf simpatis dan
meningkatkan aktivitas saraf
parasimpatis, sehingga
menyebabkan terjadinya pelepasan
endorfin yang membuat pembuluh
darah menjadi vasodilatasi (Afrila,
Dewi, \& Erwin 2015).

\section{Gambaran Intensitas Nyeri Persalinan pada Ibu Bersalin Sebelum dan Sesudah Diberikan Perlakuan Endorphin Massage}

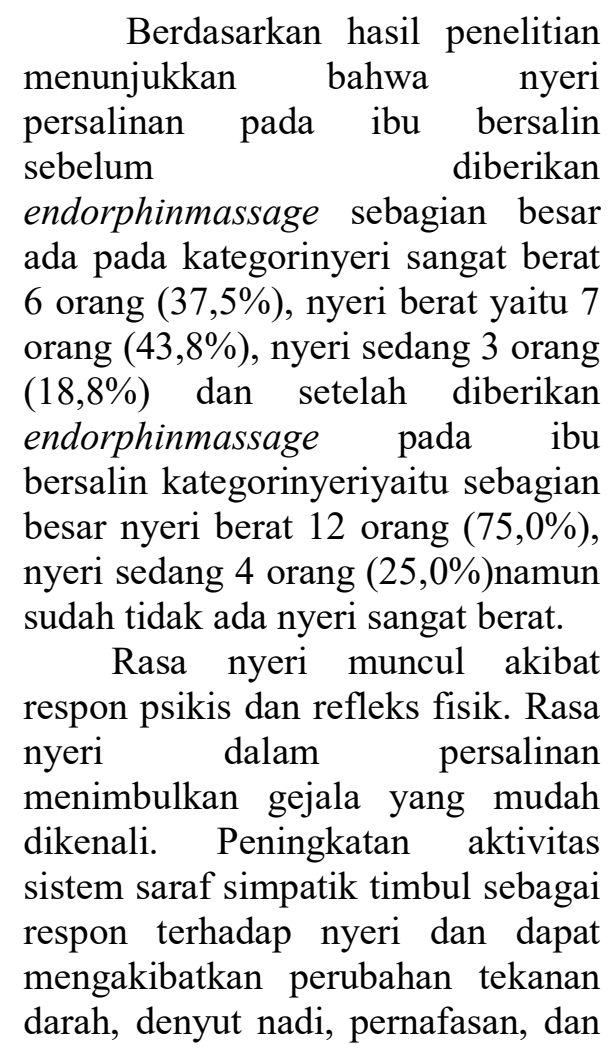

warna kulit. Perubahan afektif berupa rasa cemas disertai lapang perseptual yang menyempit, mengerang, menangis, gerakan tangan (yang menandakan rasa nyeri) dan ketegangan otot yang sangat di seluruh tubuh (Bobak dkk, 2004).

Nyeri yang dirasakan pada kala I persalinan menurut Maryunani (2013), bersifat sakit dan tidak nyaman pada fase akselerasi, nyeri dirasakan agak menusuk pada fase dilatasi maksimal, dan nyeri menjadi lebih hebat, menusuk, dan kaku pada fase deselerasi. Andarmoyo dan Suharti (2013) mengatakan bahwa nyeri persalinan sebagai kontraksi miometrium, merupakan proses fisiologis dengan intensitas yang berbeda pada masing-masing individu.

Terjadi penurunan nyeri persalinan setelah diberikan endorphin massage disebabkan karena hormon endorphin telah bekerja ketika diberikan perlakuan endorphin masage. Responden yang diberikan perlakuan endorphin massage akan mengalami relaksasi dikarenakan keluarnya hormon endorphin. Endorphin sendiri merupakan polipeptida yang terdiri dari 30 unit asam amino. Opioidopioid hormone-hormon penghilang stres, seperti kortikotrofin, kortisol, dan kotekolamin (adrenalinnoradrenalin) yang dihasilkan tubuh untuk mengurangi stres dan menghilangkan rasa nyeri (Aprilia dan Ritchmond, 2011). Selain itu, endorphin juga dapat meningkatkan sistem kekebalan tubuh/imunitas, mengurangi rasa sakit, mengurangi stres, dan memperlambat proses penuaan (Aprilia, 2010).

3. Perbedaan Pengaruh Teknik Slow Stroke Back Massage dengan Teknik Endorphin Massage Terhadap 
Penurunan Nyeri Persalinan Fase Aktif

Berdasarkan uji Mann Whitney didapatkan nilai $p$-value sebesar $0,03 p$-value $0,03<\alpha(0,05)$, maka H0 ditolak, yang berarti bahwa ada pengaruh penurunan nyeri persalinan pada ibu bersalin antara yang diberikan perlakuan Slow Stroke Back Massage dan Endorphin Massage di Wilayah Kerja Puskesmas Imbanagara Kabupaten Ciamis Tahun 2018.

Hasil analisis menunjukkan bahwa perlakuan Slow Stroke Back Massage memberikan pengaruh paling efektif dibandingkan dengan Endorphin Massage . Hal ini disebabkan karena Slow Stroke Back Massage dapat menurunkan intensitas nyeri pada kala I proses persalinan dapat dijelaskan dengan teori Opiate Endogenous. Selama kontraksi, impuls nyeri berjalan dari uterus sepanjang serabut $\mathrm{C}$ dan serat A delta untuk ditransmisikan ke sel $T$ pada Substansia Gelatinosa di medula spinalis untuk selanjutnya disampaikan menuju Korteks Serebri dan diterjemahkan sebagai sensasi nyeri.

Stimulasi taktil seperti Massage menuju sel $\mathrm{T}$ dan sel sekitar yang berada pada Substansia Gelatinosa di medula spinalis, untuk kemudian impuls yang dibawa oleh sel $\mathrm{T}$ ini dibawa menuju Periaquaductal Gray. Untuk kemudian sel ini mengeluarkan enkephalin atau serotonin yang dapat mengaktifasi sel lokal untuk mengeluarkan enkephalin. Impuls yang dibawa oleh serat $\mathrm{C}$ dan serat A delta menuju sel $\mathrm{T}$ dihambat oleh enkephalin pada presinaptik dan postsinaptik. Impuls yang berasal dari sel $\mathrm{T}$ juga menuju Midbrain yang dapat mengaktifkan kontrol penghambat yang ada pada jalur desenden.

Enkephalin merupakan zat penghilang rasa nyeri yang secara alami diproduksi oleh tubuh. Enkephalin dalam menghambat transmisi impuls nyeri bertindak sebagai neurotransmitter atau neuromodulator. Enkephalin ini berada pada sinaps saraf yang akan menurunkan sensasi nyeri. Kadar enkephalin berbeda dari satu orang dengan orang lain, hal ini menjelaskan bahwa rasa nyeri berbeda untuk tiap individu. Individu dengan kadar enkephalin tinggi akan merasakan nyeri lebih ringan. Stimulasi kulit juga dapat meningkatkan produksi enkephalin.

Mekanisme penurunan nyeri ini juga dapat dijelaskan dengan teori gate control, dimana serabut $\mathrm{C}$ dan serat A delta yang membawa impuls nyeri yang berasal dari uterus menuju gate synaps yang ada pada medula spinalis. Sedangkan serat sentuhan yang membawa impuls sentuhan dari massage juga menuju gatesynaps. Impuls yang berasal dari serat sentuhan menstimulasi serat penghambat nyeri yang dapat mengurangi intensitas impuls nyeri yang akan dibawa ke otak, sehingga dapat mengurangi rasa nyeri.

Berdasarkan uraian diatas rasa nyeri ini sangat dipengaruhi oleh persepsi nyeri yang dirasakan seseorang dan reaksi tubuh dalam merespon nyeri seperti gelisah, menangis dan menjerit serta dipengaruhi pula kehadiran pendamping saat menjelang persalinan. Nyeri ini dapat diatasi dengan menggunakan teknik slow stroke back massage dan endorphin massage. Namun lebih efektif menggunakan slow stroke back massage karena pasien langsung merasakan pijatan yang mampu 
mengurangi nyeri ke sumber rasa sakit.

\section{F. SIMPULAN DAN SARAN}

1. Simpulan

a. Nyeri persalinan kala 1 fase aktif pada ibu bersalin di Wilayah Kerja Puskesmas Imbanagara Kabupaten Ciamis tahun 2018 sebelum diberikan perlakuan slowstroke back massageada pada kategori nyeri berat, setelah diberikan perlakuan slowstroke back massageada pada kategori nyeri sedang.

b. Nyer ipersalinan kala 1 fase aktif pada ibu bersalin di Wilayah Kerja Puskesmas Imbanagara Kabupaten Ciamis tahun 2018 sebelum diberikan perlakuan endorphinmassage ada pada kategori nyeri sangat berat dan nyeri berat, setelah diberikan perlakuan endorphinmassage ada pada kategori nyer berat.

c. Terdapat perbedaan pengaruh teknik slow stroke back massage dengan teknik endorphin massage terhadap penurunan nyeri persalinan di Puskesmas Imbanagara Kabupaten Ciamis

2. Saran

a. Bagi Bidan

Metode slow stroke back massagedan endorphin massagebisa dijadikan alternatif oleh bidan untuk membantu ibu dalam proses persalinan terutama dalam menurunkan nyeri persalinan kala I dan mempercepat proses persalinan.

b. Bagi Peneliti Selanjutnya

Hendaknya peneliti selanjutnya meneliti lebih mendalam mengenai teknik endorphin massage oleh suami sebagai perbandingan penelitian serta dilakukan pengukuran nyeri persalinan pada kontraksi selanjutnya.

c. Bagi Institusi Pelayanan Institusi pelayanan kesehatan khususnya Puskesmas Imbanagara hendaknya menerapkan teknik non farmakologi dalam menurunkan intensitas nyeri persalinan salah satunya adalah teknik slow stroke back massage yang terbukti efektif dalam menurunkan intensitas nyeri persalinan, selain itu juga perlu menerapkan teknik-teknik non farmakologi lainnya seperti teknik endorphin massage.

d. Bagi Institusi Pendidikan

Hendaknya pihak institusi pendidikan memasukan kompetensi teknik non farmakologi dalam menurunkan intensitas nyeri persalinan, sehingga mahasiswa dapat mengaplikasikannya dengan kompeten ke masyarakat khusunya ibu bersalin.

\section{G. REFERENSI}

Afrila, dkk. (2015). Efektifitas Kombinasi Terapi Slow Stoke Back Massage dan Akupresur dan Akupresur terhadap Penurunan Tekanan Darah pada Penderita Hipertensi. Skripsi. JOM Vol 2 No 2

Andarmoyo, S. (2013). Konsep dan Proses Keperawatan Nyeri. Yogyakarta : Ar-Ruzz

Andarmoyo, Sulistyo, dan Suharti. (2013). Persalinan Tanpa Rasa Nyeri Berlebihan. Yogyakarta: ArRuzz Media

Arifin, L. (2008). Teknik Akupresur pada Persalinan. Arai 
Bandiyah, S. (2008). Kehamilan Persalinan Gangguan Kehamilan. Yogyakarta: Nuha Medika

Dinas Kesehatan Provinsi Jawa Barat. Profil Kesehatan Jawa Barat 2016. Bandung 2017

Kemenkes Republik Indonesia. Profil Kesehatan Indonesia Tahun 2015. Jakarta 2016

Kuswandi, lany. (2011). Kehamilan dan Persalinan dengan Hypnobirthing. Jakarta : PT Bhuana Ilmu Populer Kelompok Gramedia

M. Judha, Sudarti, Afroh, F. (2012). Teori Pengukuran Nyeri \& Nyeri
Persalinan. Yogyakarta : Nuha Medika

Maryani. (2017). Perbedaan Skala Nyeri Kala I dan Durasi Kala II Persalinan pada Primigravida dengan Senam dan Yoga Kehamilan. Skripsi

Perestroika, GD. (2014). Pengaruh Stimulasi Slow Stroke Back Massage terhadap Perubahan Kadar Endorphin dan Nyeri Persalinan pada Ibu Inpartu. Semarang : Universitas Dipenogoro Sumarah, dkk. (2009). Perawatan Ibu Bersalin (Asuhan Kebidanan pada Ibu Bersalin). Jakarta : Fitramaya 